\title{
Rethinking Psychoanalytic Ideas in Russian Philosophy
}

\author{
Tatyana I. Barmashova* \\ Krasnoyarsk State Agrarian University \\ 90 Mira, Krasnoyarsk, 660049, Russia
}

Received 14.09.2018, received in revised form 23.11.2018, accepted 06.12.2018

Despite the tendency to ignore Russian philosophy contribution to the study of the phenomenon of the unconscious, the author looks into its input into the research of the unconscious. In the theory of "common task" by N.F. Fyodorov understanding of psychoanalytic concepts is subordinated to the great task of revival of ancestors' heritage. N.A. Berdyaev interprets the unconscious from personalistic positions. S.L. Frank explicates psychoanalytic ideas in the social field. Having chosen the dialectical-religious concept B.P. Vysheslavtsev fills psychoanalytic concepts "libido", "Eros", "sublimation" with spiritual content. V.F. Ern connects the unconscious with the irrational society phenomena, characterizing the deep national traits of the German spirit. The main findings of the study are that Russian philosophy, unlike psychoanalysis, which belittles the nature of the unconscious and of man himself, extrapolates the problem of the unconscious to the metaphysical realm of being, supposing a transcendental nature in this phenomenon. Not denying, on the whole, the presence of the unconscious in the elementary acts of humankind, Russian philosophers see the basis of many mental, behavioural, and active processes as the Divine principle, which is the creator of the internal unconscious motivators of the moral and spiritual emanations of the individual.

Keywords: Russian philosophy, psychoanalysis, conscious, unconscious, libido, Oedipus complex, sublimation, archetype.

Research area: social philosophy.

Citation: Barmashova, T.I. (2018). Rethinking psychoanalytic ideas in Russian philosophy. J. Sib. Fed. Univ. Humanit. soc. sci., 11(12), 1914-1924. DOI: 10.17516/1997-1370-0366.

\section{Introduction}

There is a widespread assumption that the problem of the unconscious is generally explained within the framework of psychoanalytic theories. At the same time the existence of the idea of the unconscious is attributed to the history of philosophy. However, for no good reason the Russian philosophy falls out of sight, despite the fact

(c) Siberian Federal University. All rights reserved

* Corresponding author E-mail address: tatibar910@mail.ru

This work is licensed under a Creative Commons Attribution-NonCommercial 4.0 International License (CC BY-NC 4.0). 
that it quite thoroughly studies the problem of the unconscious. This circumstance is rightly emphasized by V.M. Leibin: “...the formation and development of psychoanalysis are not connected, as is commonly believed, with Russian natural science, and even more so with the philosophical thought $<\ldots>$ it goes without saying that, when covering this issue, the researchers do not turn to Russian philosophy. However, contrary to such widespread misapprehension, a recurrence to Russian philosophical tradition seems to be highly appropriate. Perhaps paradoxically at first glance, some of Freud's psychoanalytic ideas were shaped by Russian sources. Their consideration would help to clarify the background of the issue" (Leibin, 1990: 60). The role of Russian philosophy is pointed out by V.V. Balanovsky, who stresses the influence of N.Ya. Grot on the formation of the theoretical basis of Jung's analytical psychology in the development of the theory of libido's universal mental energy (Balanovsky, 2016).

In the conditions of insufficient attention to Russian philosophy in the context of the problem of the unconscious, the goal of the present work is to study psychoanalytic ideas as reflected by Russian thinkers. Though the material does not claim to be complete, let us explore the views of those philosophers who set forward a reflection of the problem of the unconscious as a separate subject of study.

\section{N.F. Fyodorov's idea about the resurrection of ancestors in the context of the problem of the unconscious}

N.F. Fyodorov addresses the problem of the unconscious within the framework of the concept "common task". The great thinker focuses on the archaic layer of the psyche of peoples in the form of an urge to discover the country of the dead. He finds the reflection of this aspiration in myths, legends, and legends, which embody the archetypical images of the unconscious, psychic structures of ancient humanity (Fyodorov, 1982: 34). This clearly demonstrates a certain analogy with the analytical psychology of C.G. Jung. Nevertheless, Jung assumes a plurality of archetypes, while Fyodorov mentions a single archetype only, namely the desire to resurrect ancestors. As the Russian philosopher suggests, to realize the archetype its apprehension is necessary (Fyodorov, 1982: 35).

In Fyodorov's teaching, the echo of the psychoanalytic Oedipus complex is also heard (Fyodorov, 1982: 97-102). In the concept of "common task", unlike psychoanalysis, a person's awareness of their guilt towards fathers is understood personalistically. Fyodorov understands the return of life to the parents as a paid debt, whereby a person acquires freedom, freeing oneself from the unconscious, unwitting original sin against 
the Holy Spirit. Not to take responsibility for this sin, not to take part in the resurrection, means to deprive humanity of its future, to doom it to a half-animal state, to bring the destruction of culture closer. Thus, to heal the personality psychoanalysis uses the perception of the unconscious as having the vicious content, whereas Fyodorov believes that when people unite, not only in their feelings but also in their actions, "I recognize" implies "I resurrect", "I participate" in the general resurrection, which contributes to healing society as a whole and improving culture.

Like in psychoanalysis, Fyodorov attributes the inconsistency of human nature to the phenomenon of the unconscious. However, unlike Freud, he sees the reason for this not in the tripartite personality structure (Id, ego, super-ego), but in the unconsciousness of intersubject relations, in the denial of kinship and community of humanity. A man in oneself produces a split - his "I", like a son or a brother, rebels against his "I", against himself having renounced brotherhood and fatherland. The infidelity to fathers and brothers (in which, according to the philosopher, lies all the evil and vice of the world) gave rise to the discontent of man with oneself and influenced the inner spiritual world, which depends on the outer world like all others do.

As a necessary condition for the realization of the universal goal of the resurrection, Fyodorov puts forward supramoralism, which stipulates the highest morality, the desire to be perfect and similar to the Creator, and which is manifested in the form of a conscious duty of resurrection in relation to ancestral fathers. Supramoralism helps to avoid death caused by the unconscious force of separation, ensuring immortality. Ultimately, the philosopher joins overcoming unconsciousness with the Triune God (Fyodorov, 1982: 540).

\section{Personalistic interpretation of the unconscious by N.A. Berdyaev}

The rethinking of psychoanalytic ideas was also carried out by N.A. Berdyaev. The reasons for the split soul Berdyaev identifies in the confrontation of the subconscious and consciousness. In this the philosopher supports one of the basic tenets of psychoanalysis. Meanwhile, Berdyaev does not accept the biological emphasis of classical psychoanalysis, revealing an ambiguous attitude towards it. The philosopher credits the main drawback of psychoanalysis with ignoring the spiritual life of a person. Describing the essence of psychoanalysis, Berdyaev highlighted that "the image of God in man is completely obscured and concealed, it is not visible behind the darkness of the unconscious and behind the lies of consciousness" (Berdyaev, 1993: 76). Not rejecting the presence of a number of biologically determined manifestations of the 
unconscious, Berdyaev actualizes along with them those forms of the unconscious that personify the sphere of the transcendent human striving for the Divine principle.

At the same time, Berdyaev differently characterizes the role of consciousness, which in psychoanalysis is intended to play the role of a healing factor. He disagrees about the desirable awareness of the content of the unconscious, being confident that sex life should rest in the field of the unconscious. It is the dictate of consciousness in relation to the unconscious which the philosopher assumes being the determinant of nervous-mental diseases. Unlike Freud, Berdyaev assigns the unconscious a positive meaning and determines consciousness negatively.

According to this understanding, Berdyaev reveals his vision of the problem of healing the human soul, oriented not towards consciousness, but towards the superconsciousness or spirit. As the philosopher states, the healing of the human soul is not feasible through moral consciousness, which eventually causes the nervous and mental illnesses of the individual. The thinker proposes to create a new ethic, based on spiritual energy instead of the prescriptions and requirements of consciousness. In this context, Berdyaev draws on the Christian idea of grace, which preserves the moral health of a person by eliminating sins. Berdyaev also considers creativity a means of healing the soul. A new ethic that opposes the attitudes of psychoanalysis, by virtue of its spiritual content, leads to overcoming the simplified interpretation of the problem of the unconscious, allowing us to speak about the spiritual being of the personality.

In his work, Berdyaev appeals to the Freudian idea of the Oedipus complex, perceiving it critically. The philosopher interprets the Oedipus complex in the context of a conscious-unconscious confrontation of the sexes for supremacy. "In the light of the day, in the consciousness, Oedipus is an innocent sufferer, but in the subconscious he rebelled against his father, against the winning masculine principle and wanted to connect with his mother, with the feminine principle of the earth" (Berdyaev, 1993: 68). According to Berdyaev, the Oedipus complex is expressed primarily in the fact that the masculine principle prevails in society resulting in the dominance of its norms. The protest against the father is expressed in various social phenomena, namely, in opposition to the authorities, laws, norms, etc. It is sexual differentiation that impedes the peaceful coexistence of people. Berdyaev is convinced that only by preserving integrity, like the androgyne, a person remains chaste and sophian, overcoming confrontation and achieving harmony of being. As a result of the separation of sex and the loss of the personal integrity, subconscious sex energy accumulates and then initiates neuroses and mental illnesses. The philosopher offers to find a way out in the sublimation of sexual 
energy, and not in its elimination. In this regard, Berdyaev's position is consonant with Freud's position. However, he blamed the founder of psychoanalysis for ignoring the metaphysical nature of the problem of the unconscious. As a consequence of this, classical psychoanalysis concentrates all attention on the biological side of human existence, rather than discerning in it the image and likeness of God.

\section{S.L. Frank on psychoanalytic mechanisms in the social sphere}

Psychoanalytic ideas are analyzed in a certain way in the works of SL. Frank. In his rethinking of the inconsistency of personality, he agrees with psychoanalysis. According to the philosopher, the personality "is given to us only through the medium of duality..., which even such a naturalistic-minded researcher like Freud had to admit, distinguishing simple Ego from Super-Ego or ideal Ego in the Self" (Frank, 1990: 409). Having said this, Frank goes further in understanding the personality, which represents the unity of our spiritual life, its substantial form. As for the philosopher, the secret of the individual is determined by the soul, which has a habit of rising above itself, to be on the other side of itself, on the other side of every factual state and even of its actual common nature, because it obeys the laws of transcendence.

Frank extrapolates psychoanalytic mechanisms to some social phenomena as well. Analyzing the Russian intellectual type, Frank accentuates unconscious impulses in his mental life. A manifestation of this is a dislike for wealth, which the intelligentsia is even afraid of. As a result, the love for the poor turns into a love of poverty. Frank defines a similar social mindset as an unconscious metaphysical instinct that opposes wealth (Frank, 1990: 95-101).

Frank interprets the attitude of the intelligentsia towards the people from a psychoanalytic point of view. Intellectuals considered the people an innocent victim of exploitation and oppression. The philosopher believes that this position is an unconscious atoning sacrifice. For the emergence of guilt feeling it was enough just to admit the fact that an intellectual lived in incomparably better conditions. Only selfless service to the common folks and revolutionary activities could facilitate the redemption of guilt. This necessarily brought the ambivalence of feelings, as mentioned by S. Freud. Love for the people, sympathy for their sufferings were accompanied by hatred for the "enemies of the people" and revolutionary destructive rage.

Describing the obsessive nature of revolutionary ideas, similar to the obsessive ideas of neurotics in psychoanalysis, Frank refers to the notion of repression. In this regard, he writes about the protective mechanism of the intelligentsia's adaptation 
to reality, as a result of which all the painful and unpleasant feelings (in this case, mismatch of intentions and reality) are driven into the unconscious depths. As a rule, the subject cannot and does not wish to admit to oneself unconscious blindness or the bankruptcy of faith.

At times when Frank relates to the phenomenon of the idolatry of the revolutionary faith, his ideas also intersect with psychoanalytic ones. He noted that the essence of idolatry has nothing to do with the inadequate reflection of socio-political ideals. The main distinguishing feature of this phenomenon is the worship of the correspondent social ideas as an idol and a deity. The stability of the revolution idol is determined by its rootedness in the unconscious depths of the spirit. From Frank's understanding of idolatry, it is understandable that he understood it not quite identically with the psychoanalytic concept. According to Freud, an idol is a projection of the relationship between father and dependent sons in primitive society, which subsequently generated all the similar relations between gentlemen and subordinates, leaders and the mass (Freud, 1998). E. Fromm reckons that the source of this phenomenon is determined by helplessness, human vulnerability (Fromm, 1998). Unlike classical psychoanalysis and neo-Freudianism, Frank transfers the problem to the spiritual realm of society, expressing the ideological and political views of the social subject.

\section{B.P. Vysheslavtsev: metaphysical interpretation of the concepts of eros, libido, sublimation}

Religious philosopher B.P. Vysheslavtsev also brought the problem of the unconscious to the heights of the human and divine spirit. He critically rethinks the content of psychoanalysis and creates an individually unique concept of the unconscious. The main feature of his view is the transfer of the problem of the unconscious into the plane of the spiritual, metaphysical. In this context, he addresses the issues of personal development, person's connection with God. While in psychoanalysis the unconscious is associated with the immoral manifestations of human activity, Vysheslavtsev asserts that the subconscious represents a sphere of infinite possibilities from which vice and virtue arise (Vysheslavtsev, 1994: 44-45).

Vysheslavtsev uses a number of notions from the psychoanalytic concept, in particular the notions of libido and sublimation. At the same time, he takes them not in an unchanged form, but tries to interpret them in a religious-philosophical vein. He advocates the need to remove these concepts out of the sexual sphere. In accordance with this, he interprets Eros in a broad sense as a connecting and binding force, having 
many-sided manifestations - Eros physical, mental, spiritual, angelic and divine (Vysheslavtsev, 1994: 46).

Vysheslavtsev understands sublimation in a peculiar way, too. It represents the restoration of the originally divine form, which heads for God. As he points out: "Sublimation... is a fundamental philosophical category, which found its first brilliant interpretation in the idea of Plato's Eros and received a different, more sober expression by Aristotle in the concept of form and matter" (Vysheslavtsev, 1994: 232). Considering sublimation as a philosophical category, Vysheslavtsev justifies again and again the principle of polysemanticism of manifestations denoted by this concept. He admits not only Eros of love, but also Eros of hatred, not only constructive Eros, but also Eros of degradation and destruction (Vysheslavtsev, 1994: 48-54).

Vysheslavtsev considers sublimation of Eros to be the highest sublimation with the help of imagination, which, unlike the rationally imperative rule of law, enjoys a special gift of penetration into the subconscious. In this sense, the philosopher looks upon art as the transfiguration of the lower unconscious and subconscious forces, their elevation to the higher, the great impulse to sublimation, the call for the transfiguration of the whole life (Vysheslavtsev, 1994: 52). He assigns the most important role in sublimation to freedom, which " ... rises above all the material of emotions, desires, affects, directing and changing the involuntary unconscious, successful and unsuccessful, sublimation; <...> Freedom is responsible for the entire contents of the consciousness and subconsciousness (Vysheslavtsev, 1994: 92).

Thus, the philosopher considers the culture of emotions and aspirations, oriented to the value system, the sublimation of Eros, the sublimation of the subconsciousness. So the concept of sublimation, as he himself underlines, completely ceases to be Freudian, falling out of the scope of rationalistic and naturalistic concepts. Freud's philosophical mistakes are explained by Vysheslavtsev as the impossibility of a naturalist (for example, a psychiatrist) to penetrate into the metaphysical sphere of the spirit by means of natural science concepts (Vysheslavtsev, 1994: 106-109). Unlike Freud, Vysheslavtsev interprets sublimation as an erection above nature, the construction of the lower to the higher. The pinnacle of sublimation is adoration, the limit of perfection is Absolute Perfection, or God (Vysheslavtsev, 1994: 220-221).

\section{V.F. Ern on the unconscious complexes of the German spirit}

The mentioning of psychoanalytic ideas one can find in the philosophical arguments by V.F. Ern. In the meantime, the thinker examines not only the individual, 
but also the collective psyche. He even applies some of the concepts by C.G. Jung (Jung, 1997), in particular, when he defines the judgment "Things existent can create existing" as an archetype of dialectics (Ern, 1991: 438). It should be noted that some modern Russian researchers are also developing the ideas of analytical psychology by C.G. Jung, solving the problem of transitions between the conscious and unconscious states of the subject on the basis of quantum theory, which substantiates the idea of a unity between quantum world and the collective unconscious (Petrenko, 2018).

As V.F. Ern presumes, the theoretical positions of thinkers can unconsciously reflect the deeply lying content of the psychology and consciousness of various social communities, for example nations, and affect their practical actions. In this respect, Ern colligates the philosophy of I. Kant with the all-Germanic participation in the tremendous mystery of deicide that took place in the unconscious depths of the German spirit. At the heart of this tragedy, Ern recognises unconscious guilt, realized in the haughty arrogance of the Germans regarding other people and God. According to V.F. Ern, I. Kant's philosophy was an expression of the shifts being made in the unconscious depths of the Germans self-consciousness. At the basis of this, the philosopher catches the sight of a certain deep confusion of the German spirit, called the sexual moment of the national-collective life. V.F. Ern links this to the fact that in the process of historical self-identification, the German people adopted the anomaly of abstract masculinity and the denial of positive femininity as a common social midset (Ern, 1991: 311-325). Hereof I would like to specify that some modern Russian researchers connect Kant's works with analytical psychology, in particular, they trace the Kantian influence in the concept of C.G. Jung. So, for example, V.V. Balanovsky suggests using the Jung's theory as knowledge, illuminating the unconscious structures of the psyche within the framework of the Kantian aprioristic paradigm (Balanovsky, 2015).

Touching on the problem of the "sublimated" psyche invasion, Ern actually agrees with S. Freud's views. But, unlike the founder of psychoanalysis, Ern tells about the necessity of freeing consciousness from the evil modalities of the psyche with their unconsciousness, which should implement the task of realizing the intuition in the things existent and asserting true humanity.

\section{Conclusion}

Analyzing the idea of the unconscious in Russian philosophy, one should draw a conclusion about its originality in comparison with psychoanalytic concepts. Psychoanalysis, with its naturalistic approach and a mundane understanding of human 
nature, could not satisfy Russian thinkers who aspired to the transcendent. They add a metaphysical and religious depth to the problem of the unconscious. Seeing man as being irrational, at the same time they considered man to be a creature striving for higher values, for higher Divine existence, and attributed the main task of man to realizing their likeness of God and to moral perfection of personality. In psychoanalysis, the awareness of the content of the unconscious only relieves a person from neurosis, without any affecting the spiritual development of the personality.

Another important point in Russian philosophy is to transfer the problem of the unconscious to the social sphere. The concept of the unconscious is viewed in the context of such important philosophical problems as the interaction of man and nature, the cosmos, the role of cultural-historical traditions, the essence of the historical process, the relationship of generations, the meaning of life and the destiny of man and humanity. Thus, the concept of the unconscious is filled with philosophical content; it is given an axiological dimension. This approach helps to better understanding of a person in the fullness of their natural and spiritual potencies and enriches significantly the overall picture of the complex phenomenon of the unconscious.

\section{References}

Balanovsky, V.V. (2015). Kantovskii sled v kontseptsii K.G. Iunga: zachem iskat'? Gde iskat'? [Kant's trace in the concept of C.G. Jung: what is the reason to look for? Where to look for?]. In Voprosy filosofii [Issues of Philosophy], 1, 150-157.

Balanovsky, V.V. (2016). N.Ia. Grot i K.G. Iung: o vklade russkoi filosofii v razvitie analiticheskoi psikhologii [N.Ya. Grot and C.G. Jung: on the contribution of Russian philosophy to the development of analytical psychology], In Voprosy filosofii [Issues of Philosophy], 6, 115-124.

Berdyaev, N.A. (1993). O naznachenii cheloveka [The destiny of man]. Moscow, Publishing House "Respublika", 383 p.

Berdyaev, N.A. (1999). Samopoznanie [Self-knowledge]. Moscow, EKSMO-Press, 624 p.

Berdyaev, N.A. (2000). Tvorchestvo i ob'ektivatsiia [Creativity and objectification]. Minsk, Econom-Press, 304 p.

Ern, V.F. (1991). Bor'ba za logos: Sochineniia [The struggle for logos: Writings]. Moscow, Publishing House "Pravda", 11-294.

Ern, V.F. (1991). Smysl ontologizma Dzhoberti v sviazi s problemami sovremennoi filosofii: Sochineniia [Joberty's ontologism meaning in connection with the problems of modern philosophy: Writings]. Moscow, Publishing House "Pravda", 401-430. 
Frank, S.L. (1990). Etikanigilizma (Kkharakteristike nravstvennogo mirovozzreniia russkoi intelligentsia): Sochineniia [Ethics of nihilism (On the characteristics of the moral worldview of the Russian intelligentsia): Writings]. Moscow, Publishing House "Pravda", 77-112.

Frank, S.L. (1990). Nepostizhimoe. Ontologicheskoe vvedenie v filosofiu religii: Sochineniia [Incomprehensible. An Ontological Introduction to the Philosophy of Religion: Writings]. Moscow, Publishing House "Pravda", 183-559.

Freud, S. (1998). Psikhologiia mass i analiz chelovecheskogo Ia [The psychology of the masses and analysis of the human Ego]. In Ia i Ono: Sochineniia [The Ego and the Id: Writings]. Moscow, EKSMO-Press, 769-838.

Fromm, E. (1998). Zdorovoe obshchestvo [Healthy society]. In Muzhchina $i$ zhenshchina [Man-Woman]. Moscow, Publishing House "AST", 129-452.

Fyodorov, N.F. (1982). Sochineniia [Writings]. Moscow, Mysl', 711 p.

Jung, C.G. (1997). Ob arkhetipakh kollektivnogo bessoznatel'nogo [On the archetypes of the collective unconscious]. In Bozhestvennyi rebenok: Analiticheskaia psikhologiia $i$ vospitanie [Divine child: Analytical psychology and education]. Moscow, Publishing House “Olymp”, 248-290.

Leibin, V.M. (1990). Freid, psikhoanaliz $i$ sovremennaia zapadnaia filosofiia [Freud, psychoanalysis and modern western philosophy]. Moscow, Politizdat, 397 p.

Petrenko, V.F. (2018). K probleme kollektivnogo bessoznatel'nogo v ramkakh filosofii postneklassicheskoi ratsional'nosti i psikhologii konstruktivizma [On the problem of the collective unconscious within the framework of the philosophy of postnonclassical rationality and the psychology of constructivism]. In Voprosy filosofii [Issues of Philosophy], 2, 89-101.

Vysheslavtsev, B.P.(1994). Etika preobrazhennogo Erosa [Ethics of the transformed Eros], Publishing House "Respublika", 14-152.

Vysheslavtsev, B.P. (1994). Vechnoe v russkoi filosofii [Eternal in Russian philosophy]. In Etika preobrazhennogo Erosa [Ethics of the transformed Eros], Publishing House "Respublika", 14-152. 


\title{
Переосмысление психоаналитических идей в русской философии
}

\author{
Т.И. Бармашова \\ Красноярский государственный аграрный университет \\ Россия, 660049, Красноярск, пр. Мира, 90
}

\begin{abstract}
Несмотря на тенденцию игнорирования русской философии в изучении феномена бессознательного, раскрывается ее активный вклад в развитие данной проблемы. В теории «общего дела» Н.Ф. Федорова осмысление психоаналитических понятий подчинено великой задаче воскрешения предков. Н.А. Бердяев интерпретирует бессознательное с персоналистических позииии. С.Л. Франк эксплицирует психоаналитические идеи в сочиальной области. В диалектико-религиозной концепции Б.П. Вышеславцев наполняет духовныл содержанием психоаналитические понятия «либидо», «Эрос», «сублимация». В.Ф. Эрн связывает бессознательное с иррациональными феноменами социума, характеризуя глубинные национальные особенности немецкого духа. Основные выводы исследования заключаются в том, что русская философия в отличие от психоанализа, приземляющего природу бессознательного и самого человека, экстраполирует проблему бессознательного в метафизическую плоскость бытия, предполагая в этом феномене трансиендентальную природу. Не отрицая в цеелом наличие бессознательного в элементарных актах человеческой активности, русские философы видят в основе многих мыслительных, поведенческих, деятельных процессов Божественное начало, являющееся творияом внутренних бессознательных побудителей моральнодуховного мира личности.
\end{abstract}

Ключевые слова: русская философия, психоанализ, сознательное, бессознательное, либидо, Эдипов комплекс, сублимаџия, архетип.

Научная специальность: 09.00.11 - сочииальная философия. 